\title{
MODIFICATION OF NON-METALLIC INCLUSIONS WITH RARE-EARTH METALS IN 50CrMoV13-1 STEEL
}

\author{
MODIFIKACIJA NEKOVINSKIH VKLJUČKOV S KOVINAMI \\ REDKIH ZEMELJ V JEKLU 50CrMoV13-1
}

\author{
Blaž Šuler ${ }^{1}$, Jaka Burja ${ }^{2}$, Jože Medved ${ }^{3}$ \\ ${ }^{1}$ SIJ Metal Ravne d.o.o., Koroška cesta 14, 2390 Ravne na Koroškem, Slovenia \\ 2Institute of Metals and Technology, IMT, Lepi pot 11, 1000 Ljubljana, Slovenia \\ ${ }^{3}$ Faculty of Natural Sciences and Engineering, Department of Materials and Metallurgy, Aškerčeva cesta 12, 1000 Ljubljana, Slovenia
}

Prejem rokopisa - received: 2018-12-13; sprejem za objavo - accepted for publication: 2019-05-06

doi: $10.17222 / \mathrm{mit} .2018 .271$

\begin{abstract}
The potential use of the rare-earth metals in clean steel production was investigated. Reactions between the non-metallic inclusions and the rare-earth metals were investigated in a cold-work tool-steel grade (50CrMoV13-1). A rare-earth metal alloy misch metal (Ce, La, Nd, Pr) was used for the inclusion modification. Aluminium oxide non-metallic inclusions that have a negative effect on the mechanical properties usually occur in the investigated steel. The experimental melts were made in a vacuum induction furnace with different rare-earth metal additions (50,150, 340, 950 and 2900) ppm. The laboratory cast ingots were hot forged and analysed with light and electron microscopy. It was found that misch metal additions influence the size, composition and type of the non-metallic inclusions in the steel. Most importantly, very small inclusions are formed at lower rare-earth metal additions (up to $340 \mathrm{ppm}$ ), but at high additions large non-metallic inclusions are formed (2900 ppm).

Keywords: non-metallic inclusions, inclusion modification, rare earth metals, clean steel
\end{abstract}

V študiji smo raziskali možnost uporabe redkih zemelj za izdelavo jekel z nizko vsebnostjo nekovinskih vključkov. Reakcije med redkimi zemljami in nekovinskimi vključki so bile raziskane v orodnem jeklu za delo v hladnem 50CrMoV13-1. Za dodatek redkih zemelj (Ce, La, Nd, Pr) smo uporabili mešanico redkih zemelj t.i. misch metal. Jeklo, ki smo ga uporabili v študiji, je zaradi svoje kemične sestave nagnjeno k tvorbi aluminatnih nekovinskih vključkov, kateri pa negativno vplivajo na lastnosti jekla. Eksperimentalni del je potekal na vakuumski indukcijski peči, kjer smo v jeklo dodajali različne količine redkih zemelj $(50,150,340,950$ in 2900) ppm. Ulite ingote smo prekovali v palice, slednje smo analizirali s pomočjo svetlobnega in elektronskega mikroskopa. Ugotovljeno je bilo, da dodatek redkih zemelj vpliva na velikost, kemično sestavo in tipe nekovinskih vključkov v jeklu. Zelo majhni nekovinski vključki so nastali pri nižjih vsebnostih redkih zemelj, za razliko od velikih nekovinskih vključkov, ki so nastali v jeklu z visoko vsebnostjo redkih zemelj.

Ključne beside: nekovinski vključki, modifikacija vključkov, kovine redkih zemelj, čistost jekla

\section{INTRODUCTION}

Cold-work tool steels, as the name suggests, are used to form or cut materials at room temperature. They have great wear resistance, high hardness, good impact toughness and they are also heat softening resistant. The 50CrMoV13-1 steel grade can be air quenched and is mainly used for cold-work applications. Typical applications include chisels, punches, river sets, driver bolts, as well as tools for hot punching and shearing. Typically, the $50 \mathrm{CrMoV} 13-1$ is air quenched from $950{ }^{\circ} \mathrm{C}$. The hardness after quenching reaches up to $61 \mathrm{HRC}$. The tempering is usually carried out in the temperature range from $150{ }^{\circ} \mathrm{C}$ to $400{ }^{\circ} \mathrm{C}$, depending on the hardness requirements.

The content and type of the non-metallic inclusions can influence the mechanical properties of the steel and lifetime of the steel components; ${ }^{1-3}$ this is especially true for high-hardness steels (such as cold-work tool steels). The term "clean steel" refers to a low level of non-me-

*Corresponding author e-mail:

blaz.suler@metalravne.com tallic inclusions. The requirements vary with the steel grade and its end use. Typically, oxides are the most common non-metallic inclusions in low-sulphur steels. Therefore, a low total oxygen content is required for a low-oxide, non-metallic inclusion content. ${ }^{4,5}$ Oxide non-metallic inclusions are typicaly composed from aluminium, calcium, magnesium, manganese and silicon oxides.

The aluminium oxide $\left(\mathrm{Al}_{2} \mathrm{O}_{3}\right)$ non-metallic inclusions are the result of $\mathrm{Al}$ deoxidation; they are solid at steelmaking temperatures and cause problems during steel casting, like nozzle clogging during continuous casting. ${ }^{6}$ Brittle $\mathrm{Al}_{2} \mathrm{O}_{3}$ non-metallic inclusions break into fragmented stringers during deformation, leaving sharp, hard particles, that deteriorate the mechanical and fatigue properties of steel. ${ }^{4}$ However, $\mathrm{Mn}$ and $\mathrm{Si}$ de-oxidation cause deformable, less-harmful inclusions, but the result is unfortunately, a higher total oxygen content, as they have worse de-oxidation properties. In order to obtain the desired low oxygen content in the steel melt, certain $\mathrm{Al}$ levels need to be guaranteed. ${ }^{7,8}$ The harmful effect of the aluminium oxide inclusions can be reduced by modification. The calcium $(\mathrm{Ca})$ treatment is the most 


\section{B. ŠULER et al.: MODIFICATION OF NON-METALLIC INCLUSIONS WITH RARE-EARTH METALS ...}

Table 1: Chemical composition 50CrMoV13-1 in mass fractions ( $w / \%)$

\begin{tabular}{|c|c|c|c|c|c|c|c|c|c|c|c|c|c|}
\hline $\mathrm{C}$ & $\mathrm{Si}$ & $\mathrm{Mn}$ & $\mathrm{P}$ & $\mathrm{S}$ & $\mathrm{Cr}$ & $\mathrm{Ni}$ & $\mathrm{Cu}$ & $\mathrm{Mo}$ & $\mathrm{V}$ & $\mathrm{Ti}$ & $\mathrm{Nb}$ & $\mathrm{Al}$ & $\mathrm{Fe}$ \\
\hline 0.48 & 0.25 & 0.54 & 0.018 & 0.005 & 3.30 & 0.18 & 0.09 & 1.60 & 0.220 & 0.0020 & 0.0050 & 0.014 & $\mathrm{Bal}$. \\
\hline
\end{tabular}

widely used technique to modify the aluminium oxide non-metallic inclusions. The Ca treatment can modify the high-melting-temperature inclusions into low-temperature melting inclusions that are present as liquid in the steel melt. The liquid inclusions can agglomerate more easily and grow, this eases the floatation and are also deformable with a round shape. ${ }^{3,4,9-11}$ Alternatively, other elements such as rare-earth metals or zirconium can be used to modify the shape, number and size of the non-metallic inclusions. ${ }^{12-14}$ In this research we used rare-earth metals (misch metal alloy) with the aim to modify the non-metallic inclusions and thus achieve "clean steel" production.

\section{MATERIALS AND EXPERIMENTAL PROCEDURE}

Bars of tool steel 50CrMoV13-1 for hot-work and cold-work applications and misch metal, with the chemical composition given in Tables $\mathbf{1}$ and $\mathbf{2}$, were used in the experimental work. The bars were melted in a vacuum induction melting furnace (VIM) with $20 \mathrm{~kg}$ capacity. The weight of materials used in each batch was around $14.5 \mathrm{~kg}$. Six different melts were made with different mass fractions of rare-earth metals (REMs). Before the melting the vacuum chamber of the induction furnace was first vacuumed to $5 \times 10^{-2}$ mbar, purged with Ar, vacuumed again to $5 \times 10^{-2}$ mbar, and then Ar was flooded to 300 mbar. The melting was carried out in a zirconia crucible. The REMs were added after the steel was completely melted through a special pre-vacuumed charger, that is a part of the VIM furnace.

Table 2: Chemical composition misch metal in mass fractions $(w / \%)$

\begin{tabular}{|c|c|c|c|c|}
\hline $\mathrm{Ce}$ & $\mathrm{La}$ & $\mathrm{Nd}$ & $\mathrm{Pr}$ & Oth. REM \\
\hline $45-55$ & $20-25$ & $15-20$ & $5-8$ & Bal. \\
\hline
\end{tabular}

The first melt consisted only of the 50CrMoV13-1 steel with no REM addition. The second melt was made with an addition of $0.1 \mathrm{~g}$ of REM per $1 \mathrm{~kg}$ of steel, the third with $0.5 \mathrm{~g}$ per $\mathrm{kg}$, the fourth with $1 \mathrm{~g}$ per $\mathrm{kg}$, the fifth with $2 \mathrm{~g}$ per $\mathrm{kg}$, and finally the sixth melt with $5 \mathrm{~g}$ per $\mathrm{kg}$ of steel. After the REM addition the melt was homogenized for 5 minutes before casting into an ingot under an argon protective atmosphere. The cast ingots' dimensions were roughly $80 \mathrm{~mm}^{3} \times 80 \mathrm{~mm}^{3} \times 300 \mathrm{~mm}^{3}$. The as-cast ingots were heated to $1175^{\circ} \mathrm{C}$ for $1 \mathrm{~h}$, after that they were hot forged into $30 \mathrm{~mm}$ round bars. The bars were air cooled to room temperature and annealed at $600{ }^{\circ} \mathrm{C}$ for $2 \mathrm{~h}$ (to achieve low hardness for easier machining). The specimens for chemical analysis and metallographic investigations were cut out of the bars in the longitudinal direction. The $\mathrm{C}$ and $\mathrm{S}$ contents were analysed with a LECO CS800, while the other elements were analysed with a Coupled Plasma-Optical Emission Spectrometer (ICP-OES Agilent 720). The microscopic examinations of the non-metallic inclusions based on the standard DIN50602 were made on an optical microscope Zeiss Axio Imager $1 \mathrm{~m}$. The electron microscopy was carried out with a scanning electron microscope Jeol JSM6510 with a X-ACT EDS using the INCA automatic non-metallic inclusion analyser. The automatic SEM non-metallic inclusion analysis was made on each steel sample (1-6). The analytical program automatically found, measured and made an EDS analysis for each inclusion on a $9 \mathrm{~mm}^{2}$ area. Only inclusions with a diameter of $0.98 \mu \mathrm{m}$ and larger were analysed.

\section{RESULTS AND DISCUSSION}

\subsection{Melting}

The results of the chemical analysis for the experimental batches are given in Table 3. The amount of REM is continuously increasing in the chemical analysis from sample 1 to 6 (higher amounts of REM added to the melt). The REM yield was around $50 \%$. The relatively low yield is attributed to the high vapour pressure of the REM at steelmaking temperatures $\left(1600{ }^{\circ} \mathrm{C}\right)$, also a thin oxide film formed on the melt surface after the REM addition. The film formation was observed during the REM alloying.

Table 3: Results of the rare-earth metal chemical analysis in the steel melt

\begin{tabular}{|c|c|c|c|}
\hline Sample & $w / \% \mathrm{Ce}$ & $w / \% \mathrm{La}$ & $\begin{array}{c}\text { Total ppm of } \\
\text { REM }\end{array}$ \\
\hline 1 & 0.0 & 0.0 & 0 \\
\hline 2 & 0.004 & 0.001 & 50 \\
\hline 3 & 0.010 & 0.005 & 150 \\
\hline 4 & 0.027 & 0.007 & 340 \\
\hline 5 & 0.070 & 0.025 & 950 \\
\hline 6 & 0.200 & 0.090 & 2900 \\
\hline
\end{tabular}

\subsection{Optical microscopy}

The DIN50602 standard method K was used for the non-metallic inclusions' evaluation under an optical microscope $(\mathrm{OM})$. The results of the non-metallic inclusion examinations are given in Table 4. The inclusions in sample 1 are classified as the AO (aluminate oxide) type in the DIN50602 standard (fragmented stringers). The inclusions in sample 6 are classified as AO and $\mathrm{OG}$ (oxide globular) type.

Table 5 clearly shows that the cleanest steel samples are 2, 3, 4 and 5. The first sample has no REM additions 
and contains small inclusions in the $\mathrm{K} 1$ and $\mathrm{K} 0$ size category, according to DIN50602 standard. The K1 and K0 size categories are expected for VIM refining. Samples 2 to 5 have inclusions that are too small to fall into any category. However, sample 6 has an increased amount of non-metallic inclusions that are large enough to fit into the K4 category. Figure 1 shows an OM example of non-metallic inclusions in sample 1 and sample 3 .

Table 4: Analysis results of non-metallic inclusion - DIN50602 method K

\begin{tabular}{|c|c|c|c|c|c|}
\hline REM (ppm) & K0 & K1 & K2 & K3 & K4 \\
\hline 0 & 9 & 4 & 0 & 0 & 0 \\
\hline 50 & 0 & 0 & 0 & 0 & 0 \\
\hline 150 & 0 & 0 & 0 & 0 & 0 \\
\hline 340 & 0 & 0 & 0 & 0 & 0 \\
\hline 950 & 0 & 0 & 0 & 0 & 0 \\
\hline 2900 & 468 & 468 & 468 & 368 & 221 \\
\hline
\end{tabular}

\subsection{Electron microscopy}

The automatic SEM non-metallic inclusion analysis gave us the size distribution, the amount and the chemical compositions of the non-metallic inclusions. The total surface area of the non-metallic inclusions is presented in Figure 2. The area of the non-metallic inclusions in the unmodified sample is $1492 \mu \mathrm{m}^{2}$. When REMs are added the non-metallic inclusion area is gradually reduced and reaches a minimum of $376 \mu^{2}$ at $150 \mathrm{ppm}$ REM addition. After further increasing the REM content, the non-metallic inclusion area rises, at $950 \mathrm{ppm}$ of REM the area is $1643 \mu^{2}$. The non-metallic inclusion area at $2900 \mathrm{ppm}$ of REM reaches a staggering $10,884 \mu \mathrm{m}^{2}$. The number and distribution of the non-metallic inclusions for all samples are shown in Figure 3. The vast majority of inclusions in all the samples are smaller than $2 \mu \mathrm{m}$ (Figure 3). The REM additions further increase the fraction of small inclusions. There are still some inclusions above $4 \mu \mathrm{m}$ when $50 \mathrm{ppm}$ REMs are added. But there are no inclusions above $4 \mu \mathrm{m}$ when $150 \mathrm{ppm}$ to $950 \mathrm{ppm}$ REMs are added. As mentioned above, further additions (2900 ppm) result in an increase of both the number and size of the non-metallic inclusions.

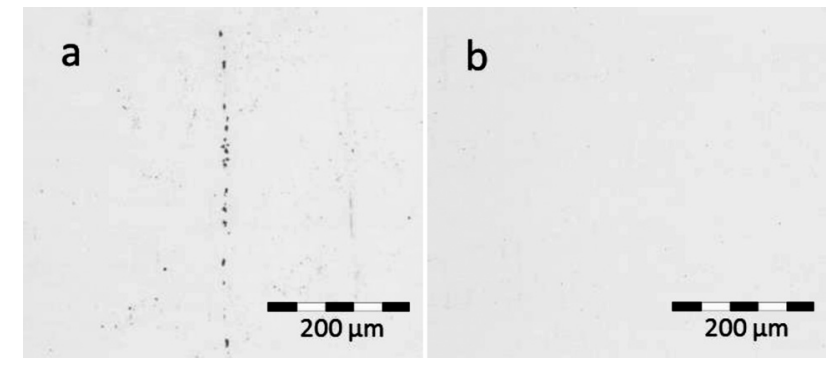

Figure 1: Optical micrographs of non-metallic inclusions in a) sample 1 - no REM and b) sample 3 - $150 \mu \mathrm{g} / \mathrm{g}$ REM

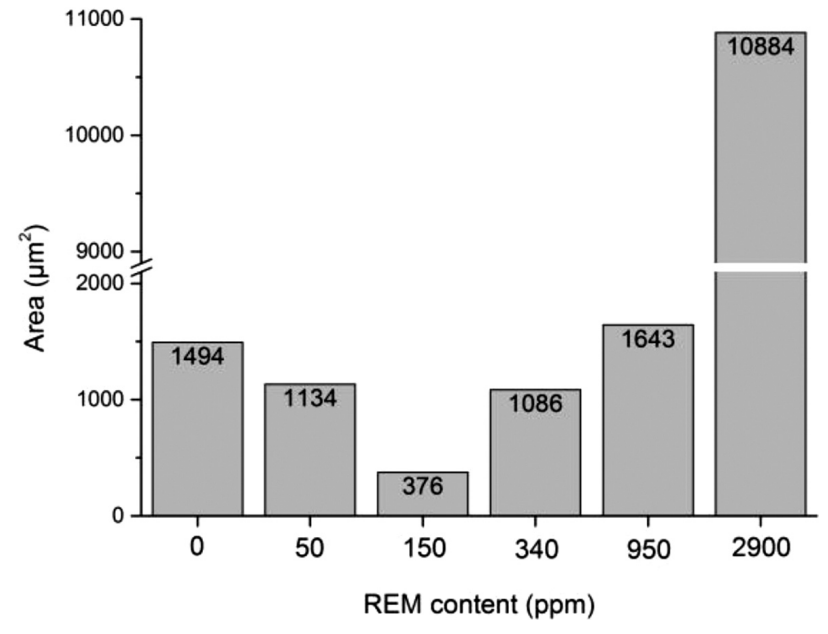

Figure 2: Area of non-metallic inclusion for all samples

The addition of REMs changed the inclusion surface area compared to the unmodified sample, $50 \mathrm{ppm}$ REM reduced it by $24 \%, 150 \mathrm{ppm}$ REM by $75 \%, 340 \mathrm{ppm}$ by $27 \%$, but 950 and 2900 ppm of REM increased the area by $10 \%$ and $728 \%$, respectively.

The chemical composition and the type of the nonmetallic inclusions also changes with the REM additions. The REM additions from $50 \mathrm{ppm}$ to $340 \mathrm{ppm}$ increase the number of oxysulphide inclusions (Figure 4). When $950 \mathrm{ppm}$ of REM are added, the number of oxides increases. This can be explained by the limited concentration of sulphur (50 ppm, see Table 1). The high oxide number is attributed to the lower oxidation states of the REMs as they form different oxides. ${ }^{14}$ Another difference between the REM modified and unmodified inclu-
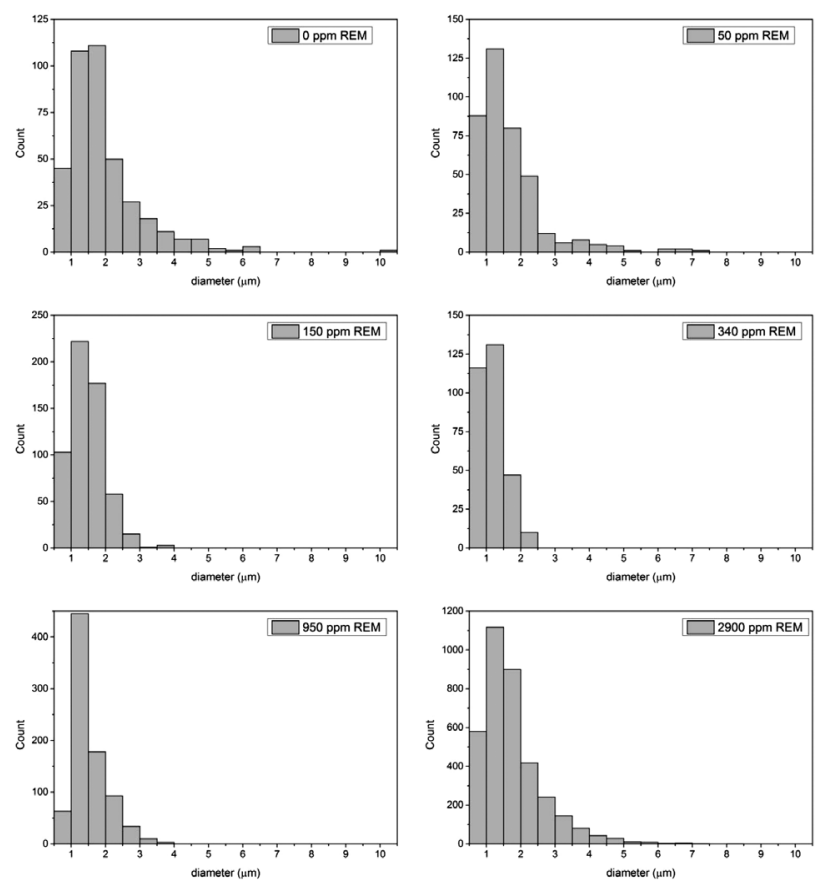

Figure 3: Number and distribution of inclusions for each sample 


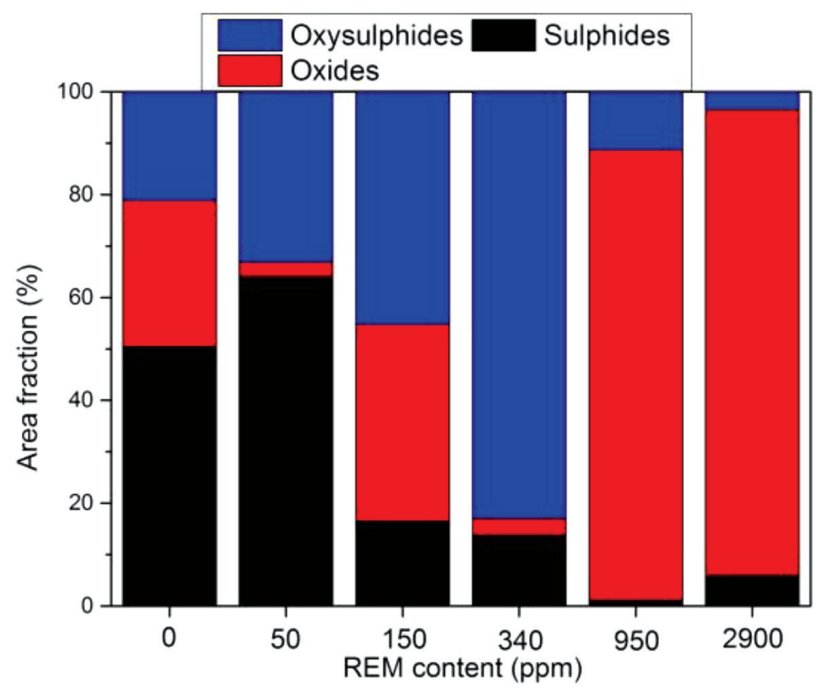

Figure 4: Type of non-metallic inclusions in the samples

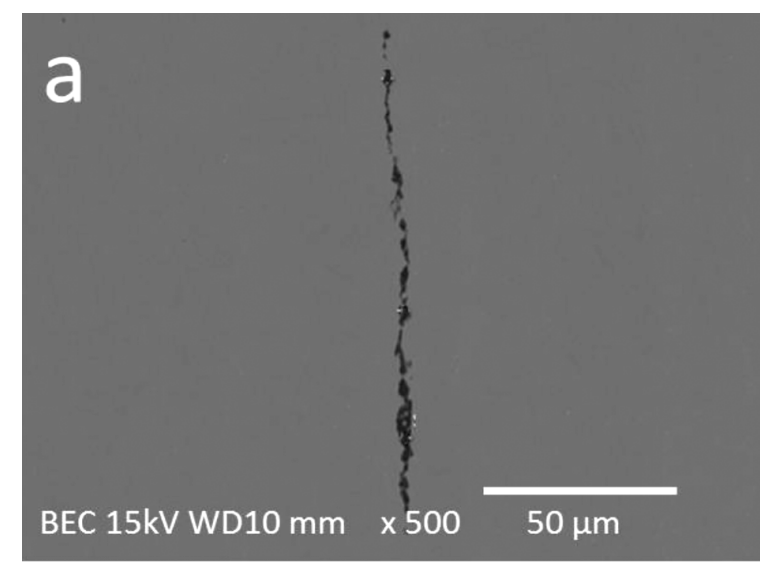

\begin{tabular}{|l|l|l|l|}
\hline \multicolumn{4}{|c|}{ EDS spectra $(w / \%)$} \\
\hline $\mathrm{A} 1$ & $\mathrm{O}$ & $\mathrm{Mg}$ & $\mathrm{Fe}$ \\
\hline 42.0 & 36.0 & 15.5 & 6.5 \\
\hline
\end{tabular}

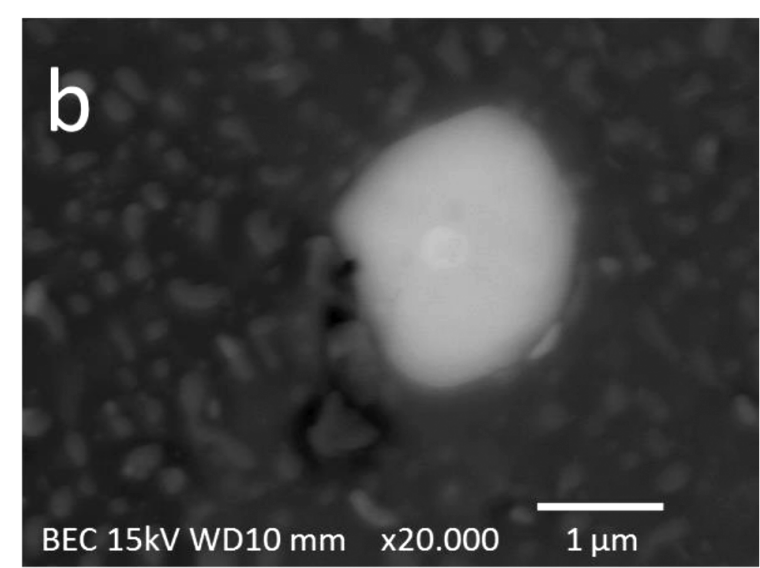

\begin{tabular}{|l|l|l|l|l|}
\hline \multicolumn{4}{|l|}{ EDS spectra $(w / \%)$} \\
\hline $\mathrm{Ce}$ & $\mathrm{La}$ & $\mathrm{O}$ & $\mathrm{Nd}$ & $\mathrm{Fe}$ \\
\hline 49.7 & 23.6 & 11.9 & 9.4 & 5.4 \\
\hline
\end{tabular}

sions is that the oxysulphides in sample $1(0 \mu \mathrm{g} / \mathrm{g}$ REM $)$ are in fact complex (multi-phase) inclusions, as is common for steels, ${ }^{15,16}$ while the REMs form oxysulphide compounds. ${ }^{14,17}$ The REM non-metallic inclusions have high atomic numbers $\mathrm{Z}$, so they appear bright in the backscattered electron images. The type of REM inclusions (oxide/sulphide/oxysulphide) is difficult to determine from the electron microscope images, as they also change little in morphology. Examples of non-metallic inclusions, (a) aluminium oxide in sample 1, (b) REM oxide in sample 3, (c) REM sulphide in sample 4 and (d) REM oxysulphide in sample 3 with the associated EDS analyses are shown in Figure 5.

The average compositions of the oxide non-metallic inclusions are shown in Figure 6a. Sample no. 1 contains mainly aluminium oxides with some $\mathrm{Si}, \mathrm{Mg}$ and $\mathrm{Ca}$. Silicon oxide is the least stable of the analysed oxides and is a common de-oxidation agent. Our samples

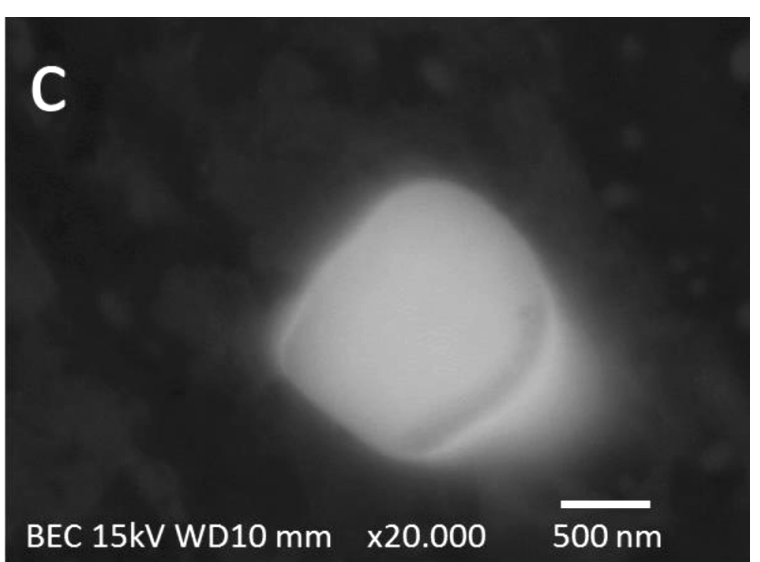

\begin{tabular}{|l|l|l|l|l|}
\hline \multicolumn{5}{|c|}{ EDS spectra $(w / \%)$} \\
\hline $\mathrm{Ce}$ & $\mathrm{La}$ & $\mathrm{Nd}$ & $\mathrm{S}$ & $\mathrm{Fe}$ \\
\hline 38.2 & 30.3 & 15.2 & 9.1 & 7.2 \\
\hline
\end{tabular}

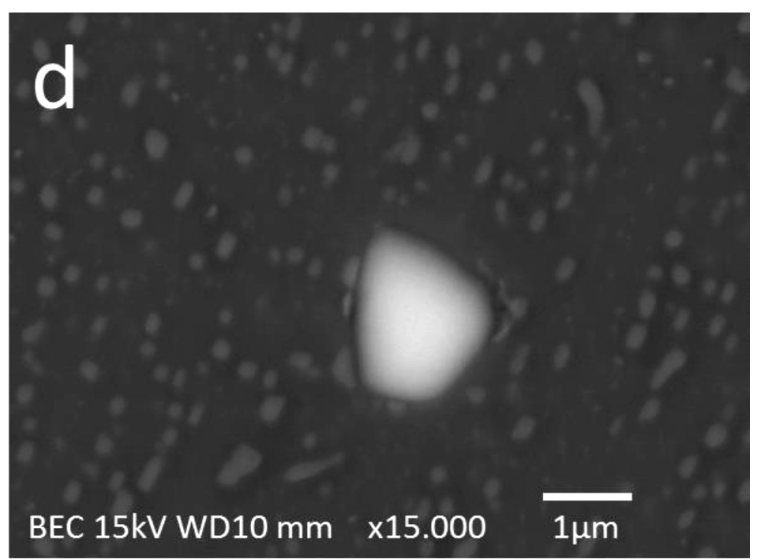

\begin{tabular}{|l|l|l|l|l|l|}
\hline \multicolumn{6}{|l|}{ EDS spectra $(w / \%)$} \\
\hline $\mathrm{Ce}$ & $\mathrm{La}$ & $\mathrm{Nd}$ & $\mathrm{S}$ & $\mathrm{O}$ & $\mathrm{Fe}$ \\
\hline 37.3 & 28.1 & 12.4 & 8.4 & 7.0 & 6.8 \\
\hline
\end{tabular}

Figure 5: a) aluminium oxide in sample 1 (0 ppm REM), b) rare-earth metal oxide in sample 3 (150 ppm REM), c) rare-earth metal sulphide in sample 4 (340 ppm REM) and d) rare-earth metal oxysulphide in sample 3 (150 ppm REM), with EDS spectra in $w / \%$ 

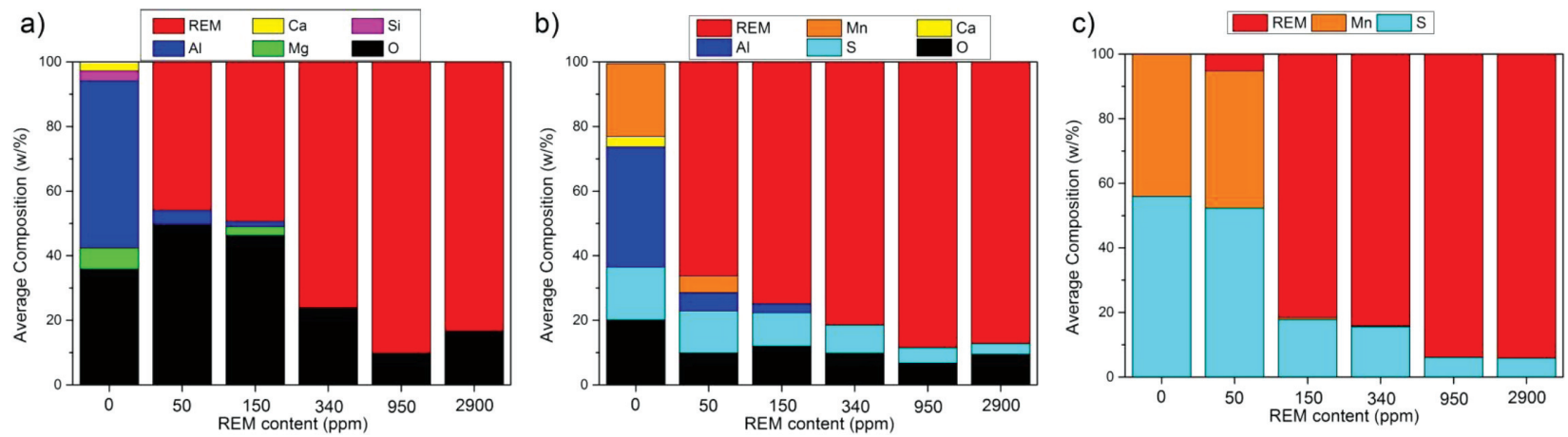

Figure 6: Chemical composition of: a) oxide non-metallic inclusions, b) oxysulphide non-metallic inclusions, c) sulphide non-metallic inclusions

did not contain silicon-based inclusions, only $\mathrm{SiO}_{2}$ dissolved in the alumina. $\mathrm{MgO} \cdot \mathrm{Al}_{2} \mathrm{O}_{3}$ spinel-type inclusions are commonly found in Al-killed steels, and are formed through refractory/slag/melt interactions. ${ }^{15}$ In our particular case the spinel-type inclusions were found as part of the fractured alumina stringers (the low magnesium content is shown in Figure 6a). $\mathrm{Ca}$ is also common and is either the result of $\mathrm{Ca}$ modification or slag/melt interaction. There were not any Ca-modified inclusions found in our case. The composition of the oxide inclusions is significantly changed after the REMs addition. The REM oxides become dominant, as a result of the thermodynamic stability.

The additions of REM cause the formation of oxysulphide inclusions, their number increases with the REM content increase. However, the maximum increase of REM oxysulphides occurred at 340 ppm REMs addition (sample 4), a further increase of the REMs content resulted in a sharp decline in oxysulphide inclusion numbers (Figure 6b). The REMs addition also resulted in the formation of REM sulphides, replacing the dominant $\mathrm{MnS}$. The addition of $150 \mathrm{ppm}$ REM completely prevented the formation of the MnS inclusions, as seen in Figure 6c. Further REM additions resulted in an increase of REM content in the non-metallic inclusions. The ratio between REM/S increased, due to the formation of different type of REM sulphides.

\subsection{Thermodynamic calculations}

Table 5: Enthalpy and entropy values for Ce oxidation reactions ${ }^{12,18}$

\begin{tabular}{|c|c|c|}
\hline Reaction & $\Delta \mathrm{H}(\mathrm{J})$ & $\Delta \mathrm{S}(\mathrm{J})$ \\
\hline $2[\mathrm{Al}]+3[\mathrm{O}]=\mathrm{Al}_{2} \mathrm{O}_{3}(\mathrm{~s})$ & -1205090 & -387.72 \\
\hline $2[\mathrm{Ce}]+2[\mathrm{O}]+[\mathrm{S}]=\mathrm{Ce}_{2} \mathrm{O}_{2} \mathrm{~S}(\mathrm{~s})$ & -1493010 & -438.9 \\
\hline$[\mathrm{Ce}]+[\mathrm{S}]=\mathrm{CeS}(\mathrm{s})$ & -422783 & -120.58 \\
\hline $20[\mathrm{Ce}]+2[\mathrm{O}]=\mathrm{CeO}_{2}(\mathrm{~s})$ & -854274.7 & -249.06 \\
\hline $2[\mathrm{Ce}]+3[\mathrm{O}]=\mathrm{Ce}_{2} \mathrm{O}_{3}(\mathrm{~s})$ & -1431090 & -360.06 \\
\hline $2[\mathrm{Ce}]+3[\mathrm{~S}]=\mathrm{Ce}_{2} \mathrm{~S}_{3}(\mathrm{~s})$ & -1074584 & -328.24 \\
\hline
\end{tabular}

As cerium is the dominant element in misch metal (Table 2), the REM additions can be described as an increase in Ce. Therefore, Ce was used for the thermodynamic calculations. The values for the reaction enthalpies and entropies are given in Table 5. The element interaction coefficients in a diluted iron melt at $1600{ }^{\circ} \mathrm{C}$ are given in Table 6. The interaction coefficients show that $\mathrm{S}$ and $\mathrm{O}$ have a major impact on lowering the $\mathrm{Ce}$ activity. The calculated Gibbs free energy values for the reaction in Table 5 at (50, 150 and 340) ppm of Ce at (1, 10 and 100) ppm of oxygen and at $1873 \mathrm{~K}$ are given in Table 7 . The thermodynamic calculations in Table 7 for the (50, 150 and 340) ppm of Ce are presented, because the experimental results are the most promising in terms of inclusion content.

Table 6: First-order interaction coefficients \# , in liquid iron at $1873 \mathrm{~K}$

\begin{tabular}{|c|c|c|c|c|}
\hline & $\mathrm{Ce}$ & $\mathrm{S}$ & $\mathrm{O}$ & $\mathrm{Al}$ \\
\hline $\mathrm{Ce}$ & $0,0039^{14}$ & $-40^{14}$ & $-106^{19}$ & $/$ \\
\hline $\mathrm{S}$ & $-9,1^{14}$ & $-0.046^{14}$ & $-0.27^{20}$ & $0.035^{20}$ \\
\hline $\mathrm{O}$ & $-64^{14}$ & $-0.133^{20}$ & $-0.17^{14}$ & $-3.9^{20}$ \\
\hline $\mathrm{Al}$ & $/$ & $0.03^{20}$ & $-6.6^{20}$ & $0.045^{20}$ \\
\hline
\end{tabular}

The thermodynamic calculations show that Ce has a high affinity for oxygen and preferably reacts with oxygen. Ce sulphide formation is only enabled at low oxygen contents (10 ppm). On the other hand, Ce oxysulphides formation is possible even at high oxygen contents $(100 \mathrm{ppm})$. This means the REM addition will primarily react with oxides in the melt $\left(\mathrm{SiO}_{2}, \mathrm{Al}_{2} \mathrm{O}_{3}\right)$ and replace them with REM-type oxides. ${ }^{21}$ At low REM contents $(50 \mathrm{ppm})$ the oxygen consumed the majority of the REM, so only REM oxides and oxysulphides are formed. But, when the REM content was increased to $150 \mathrm{ppm}$, there was enough REM left over to enable the formation of REM sulphides (as shown in Figure 6c). Table 7 also shows that the REM content itself is not as crucial to the reaction as is the oxygen activity/content. This means that the oxygen contents will dictate the REM non-metallic inclusion type formation. In comparison to the Ce oxidation, the aluminium oxide formation requires relatively high oxygen contents (100 $\mathrm{ppm})$, even at low Ce concentrations (50 ppm). The experimental results presented in Figure 6a confirm that aluminium oxides are the first to be reduced by the REM additions. 


\section{B. ŠULER et al.: MODIFICATION OF NON-METALLIC INCLUSIONS WITH RARE-EARTH METALS ...}

Table 7: Calculated Gibbs free energy for reaction products (J), at $1873 \mathrm{~K}, 50 \mathrm{ppm} \mathrm{S,} 200 \mathrm{ppm} \mathrm{Al}$

\begin{tabular}{|c|c|c|c|}
\hline \multicolumn{4}{|c|}{$50 \mathrm{ppm} \mathrm{Ce}$} \\
\hline $\mathrm{O}(w / \%)$ & $2 / 3[\mathrm{Al}]+[\mathrm{O}]=1 / 3 \mathrm{Al}_{2} \mathrm{O}_{3}$ & {$[\mathrm{Ce}]+[\mathrm{O}]+1 / 2[\mathrm{~S}]=1 / 2 \mathrm{Ce}_{2} \mathrm{O}_{2} \mathrm{~S}$} & {$[\mathrm{Ce}]+[\mathrm{S}]=\mathrm{CeS}$} \\
\hline 0.0001 & 44963.84 & -76555.1 & -22842.2 \\
\hline 0.001 & 9272.361 & -108965 & -19414.5 \\
\hline 0.01 & -25092.5 & -110515 & 14862.93 \\
\hline $\mathrm{O}(w / \%)$ & $1 / 2[\mathrm{Ce}]+[\mathrm{O}]=1 / 2 \mathrm{CeO}_{2}$ & $2 / 3[\mathrm{Ce}]+[\mathrm{O}]=2 / 3 \mathrm{Ce}_{2} \mathrm{O}_{3}$ & $2 / 3[\mathrm{Ce}]+[\mathrm{S}]=1 / 3 \mathrm{Ce}_{2} \mathrm{~S}_{3}$ \\
\hline 0.0001 & 8804.683 & -34579.8 & -9173.47 \\
\hline 0.001 & -25319.2 & -68133.9 & -6885.41 \\
\hline 0.01 & -44008.1 & -81124.4 & 15995.21 \\
\hline \multicolumn{4}{|c|}{$150 \mathrm{ppm} \mathrm{Ce}$} \\
\hline $\mathrm{O}(w / \%)$ & $2 / 3[\mathrm{Al}]+[\mathrm{O}]=1 / 3 \mathrm{Al}_{2} \mathrm{O}_{3}$ & {$[\mathrm{Ce}]+[\mathrm{O}]+1 / 2[\mathrm{~S}]=1 / 2 \mathrm{Ce}_{2} \mathrm{O}_{2} \mathrm{~S}$} & {$[\mathrm{Ce}]+[\mathrm{S}]=\mathrm{CeS}$} \\
\hline 0.0001 & 67900.73 & -69088.4 & -36681.8 \\
\hline 0.001 & 32209.25 & -101498 & -33254 \\
\hline 0.01 & -2155.58 & -103049 & 1023.372 \\
\hline $\mathrm{O}(w / \%)$ & $1 / 2[\mathrm{Ce}]+[\mathrm{O}]=1 / 2 \mathrm{CeO}_{2}$ & $2 / 3[\mathrm{Ce}]+[\mathrm{O}]=2 / 3 \mathrm{Ce}_{2} \mathrm{O}_{3}$ & $2 / 3[\mathrm{Ce}]+[\mathrm{S}]=1 / 3 \mathrm{Ce}_{2} \mathrm{~S}_{3}$ \\
\hline 0.0001 & 23191.12 & -23043.5 & -17312.7 \\
\hline 0.001 & -10932.8 & -56597.6 & -15024.7 \\
\hline 0.01 & -29621.7 & -69588.1 & 7855.954 \\
\hline \multicolumn{4}{|c|}{340 ppm Ce } \\
\hline $\mathrm{O}(w / \%)$ & $2 / 3[\mathrm{Al}]+[\mathrm{O}]=1 / 3 \mathrm{Al}_{2} \mathrm{O}_{3}$ & {$[\mathrm{Ce}]+[\mathrm{O}]+1 / 2[\mathrm{~S}]=1 / 2 \mathrm{Ce}_{2} \mathrm{O}_{2} \mathrm{~S}$} & {$[\mathrm{Ce}]+[\mathrm{S}]=\mathrm{CeS}$} \\
\hline 0.0001 & 111480.8 & -35149.4 & -43224.6 \\
\hline 0.001 & 75789.33 & -67559.4 & -39796.8 \\
\hline 0.01 & 41424.5 & -69109.6 & -5519.44 \\
\hline $\mathrm{O}(w / \%)$ & $1 / 2[\mathrm{Ce}]+[\mathrm{O}]=1 / 2 \mathrm{CeO}_{2}$ & $2 / 3[\mathrm{Ce}]+[\mathrm{O}]=2 / 3 \mathrm{Ce}_{2} \mathrm{O}_{3}$ & $2 / 3[\mathrm{Ce}]+[\mathrm{S}]=1 / 3 \mathrm{Ce}_{2} \mathrm{~S}_{3}$ \\
\hline 0.0001 & 60401.53 & 12043.67 & -19609.1 \\
\hline 0.001 & 26277.64 & -21510.4 & -17321 \\
\hline 0.01 & 7588.741 & -34500.9 & 5559.595 \\
\hline
\end{tabular}

\section{CONCLUSIONS}

Rare-earth metal (REM) additions cause changes in the non-metallic inclusion chemistry, size and distribution. Three types of REM-based non-metallic inclusions are formed: oxides, sulphides and oxysulphides. The modification and refining of the non-metallic inclusions confirm that REMs show potential in "clean steel" production.

The maximum non-metallic inclusion area-surface reduction, compared to the unmodified sample, was 75 $\%$ at 150 ppm REM.

Lower additions of REMs (50 ppm) will modify oxides and oxysulphides, but not sulphides. Higher REM $(150 \mathrm{ppm})$ will result in the elimination of all nonREM-based inclusions $\left(\mathrm{Al}_{2} \mathrm{O}_{3}, \mathrm{MnS}, \mathrm{SiO}_{2}, \mathrm{MgO} \cdot \mathrm{Al}_{2} \mathrm{O}_{3}\right)$.

REM additions produced smaller/finer non-metallic inclusions. The number of detectable inclusions $(<0.98$ $\mu \mathrm{m})$ increased, while the total non-metallic inclusion area decreased, the minimum was reached at $150 \mathrm{ppm}$ REM.

Higher REM additions resulted in more and larger non-metallic inclusions, worsening the steel's cleanliness. Very high REM additions (2900 ppm REM) greatly increased the number and size of the non-metallic inclusions.

\section{REFERENCES}

${ }^{1}$ R. Arreola-Herrera, A. Cruz-Ramírez, J. E. Rivera-Salinas, J. A. Romero-Serrano, R. G. Sánchez-Alvarado, The effect of non-metallic inclusions on the mechanical properties of $32 \mathrm{CDV} 13$ steel and their mechanical stress analysis by numerical simulation, Theor. Appl. Fract. Mech., 94 (2018), 134-146, doi:10.1016/j.tafmec.2018. 01.013

${ }^{2}$ M. Jiang, X. Wang, B. Chen, W. Wang, Laboratory study on evolution mechanisms of non-metallic inclusions in high strength alloyed steel refined by high basicity slag, ISIJ Int., 50 (2010), 95-104, doi:10.2355/isijinternational.50.95

${ }^{3}$ L. Zhang, B. G. Thomas, State of the art in the control of inclusions during steel ingot casting, Metall. Mater. Trans. B, 37 (2006), 733-761, doi:10.1007/s11663-006-0057-0

${ }^{4}$ H. Y. Tang, Y. Wang, T. Wu, J. S. Li, S. F. Yang, Characteristics analysis of inclusion of $60 \mathrm{Si}_{2} \mathrm{Mn}-\mathrm{Cr}$ spring steel via experiments and thermodynamic calculations, Ironmak. Steelmak, 44 (2017) 5, 377-388, doi:10.1080/03019233.2016.1212563

${ }^{5}$ K. Steneholm, N. A. I. Andersson, A. Tilliander, P. G. Jönsson, The role of process control on the steel cleanliness, Ironmak, Steelmak., 0 (2016) 1-11, doi:10.1080/03019233.2016.1245917

${ }^{6}$ F. Tehovnik, J. Burja, B. Arh, M. Knap, Submerged entry nozzle clogging during continuous casting of al-killed steel, Metalurgija, 54 (2015)

${ }^{7}$ Z. Deng, M. Zhu, Deoxidation mechanism of al-killed steel during industrial refining process, ISIJ Int., 54 (2014), 1498-1506, doi:10.2355/isijinternational.54.1498

${ }^{8}$ M.-K. Paek, J.-M. Jang, Y.-B. Kang, J.-J. Pak, Aluminum deoxidation equilibria in liquid iron: Part I: Experimental, Metall. Mater. Trans. B, 46 (2015) 4, 1826-1836, doi:10.1007/s11663-015-0368-0 


\section{B. ŠULER et al.: MODIFICATION OF NON-METALLIC INCLUSIONS WITH RARE-EARTH METALS ...}

${ }^{9}$ R. Dekkers, B. Blanpain, P. Wollants, F. Haers, C. Vercruyssen, B Gommers, Non-metallic inclusions in aluminium killed steels, Ironmak. Steelmak., 29 (2002), 437-444, doi:10.1179/ 030192302225004584

${ }^{10}$ Y. Ren, L. Zhang, S. Li, Transient evolution of inclusions during calcium modification in linepipe steels, ISIJ Int., 54 (2014), 2772-2779, doi:10.2355/isijinternational.54.2772

${ }^{11}$ Y. Wang, S. Sridhar, M. Valdez, Formation of $\mathrm{CaS}$ on $\mathrm{Al}_{2} \mathrm{O}_{3}-\mathrm{CaO}$ inclusions during solidification of steels, Metall. Mater. Trans. B, 33 (2002), 625-632, doi:10.1007/s11663-002-0042-1

${ }^{12}$ Y. Li, C. Liu, T. Zhang, M. Jiang, C. Peng, Liquid inclusions in heat-resistant steel containing rare earth elements, Metall. Mater. Trans. B, 48 (2017), 956-965, doi:10.1007/s11663-016-0873-9

${ }^{13}$ M. Koležnik, J. Burja, B. S. Batič, A. Nagode, J. Medved, De-oxidation of Pk942 steel with Ti and Zr, Mater. Tehnol., 51 (2017), 1031-1036, doi:10.17222/mit.2017.082

${ }^{14}$ F. Pan, J. Zhang, H.-L. Chen, Y.-H. Su, Y.-H. Su, W.-S. Hwang, Thermodynamic calculation among cerium, oxygen, and sulfur in liquid iron, Sci. Rep., 6 (2016) 35843, doi:10.1038/srep35843

${ }^{15}$ J. H. Shin, J. H. Park, Formation mechanism of oxide-sulfide complex inclusions in high-sulfur-containing steel melts, Metall. Mater. Trans. B, 49 (2018), 311-324, doi:10.1007/s11663-017-1152-0
${ }^{16}$ L. Krajnc, P. Mrvar, J. Medved, Thermodynamic characterization of multiphase non-metallic inclusions in re-sulphurised steel grades, Mater. Tehnol., 48, (2014), 923-929

${ }^{17}$ K. Zelič, J. Burja, P. J. McGuiness, M. Godec, Effect of rare earth elements on the morphology of eutectic carbides in AISI D2 tool steels: Experimental and modelling approaches, Scientific Reports, 8 (2018), 9233, doi:10.1038/s41598-018-27658-w

${ }^{18}$ Y. Li, C. Liu, C. Li, M. Jiang, A coupled thermodynamic model for prediction of inclusions precipitation during solidification of heat-resistant steel containing cerium, J. Iron Steel Res. Int., 22 (2015), 457-463, doi:10.1016/S1006-706X(15)30027-3

${ }^{19}$ Q. Han, C. Xiang, Y. Dong, S. Yang, D. Chen, Equilibria between the rare earth elements, oxygen and sulfur, in molten iron, Metall. Mater. Trans. B, 19 (1988) 3, 409-418

${ }^{20}$ G. K. Sigworth, J. F. Elliot, The thermodynamics of liquid dilute iron alloys, Met. Sci. B, (1974), 298-310

${ }^{21}$ S. K. Kwon, J. S. Park, J. H. Park, Influence of refractory-steel interfacial reaction on the formation behavior of inclusions in Ce-containing stainless steel, ISIJ Int., 55 (2014), 2589-2596, doi:10.2355/isijinternational.ISIJINT-2015-125 